トピック

\title{
印刷産業におけるマルチメディアと情報知識学 Multimedia and Information \& Knowledge in the Printing Industries
}

\author{
深見 拓史 \\ 凸版印刷 (株) 生産・技術開発部
}

印刷産業におけるデジタル化の現状と課題、特にここ数年間における印刷前工程（プ リプレス工程）でのデジタル化の進展はめざましいものがある。当然デジタル化さ れた情報は単に紙メディアのみならずCDーR OMやインターネットにも活用され 始めてきた。このようなマルチメディア化の進展と将来の方向性、情報流通の動き や情報と知識に関する考え方、印刷産業から情報コミュニケーション産業への課題 についてものべる。

\section{1.はじめに}

印刷業のデジタル化の動きが加速されたの は最近のことであるが、実は 10 年毎に新し いコンピュータ化が進展している。約 30 年 ほど前にホストコンピュータを利用して百科 事典や辞典類などの編集を始めたのが最初で あった。従来の鉛活字ではなくコンピュータ 文字を用いたためにホットタイプセッティン グシステム (活字) ではなくコールドタイプ セッティングシステム (CTS) と呼ばれたり した。その後写真を 4 つの色成分に分解する ためにそれまでの大型力メラ方式からカラー スキャナーによるスキャニング方式に変化し やがてこれがデジタル化されトータルスキャ ナーシステムとして注目を浴び始めたのが 2 0 年ほど前のことである。

印刷産業とは、表面加工技術を製造技術と して大量・安価に複製する技術を有する産業 のことであった。商業印刷物や出版印刷物に おいては販売促進のための商品情報や読み物 としての取材記事などを大量複製することで ある、紙とインキを材料として企業が伝えた い商品情報をカタログやチラシの形で消費者 に伝えたり、著者の伝えたい情報を畫籍や雑
誌の形で読者に伝える。すなわち印刷会社は、 お得意先の商品情報や著者の意思を正確に品 質良く最適なコストでお得意先に代わって企 画編集制作し大量に複製する。いわばアウト ソーシング業そのものといえる。

また、コンピュータの発達とあいまって最 近ではすべての情報がデジタル化されること によって、大きな変化が現れ始めた。デジタル 化された情報の品質は劣化することなく、い くらでもコピー可能となり、しかもインター ネットなどのネットワークの発達により瞬時 に世界中のあらゆる場所に伝達できるように なった。従来、お得意先から原稿を受け取り、 それにデザインを加え写植文字処理やカラー 写真を 4 色分解フィルムに処理するなよ゙、い わゆるアナログ製版した後、印刷によって大 量に複製していたものが、文字・図形・画像お よびレイアウトなどすべての構成要素がデジ タル化されると、大容量の CD-ROM に収納 されたり、簡単にネットワークで読者に届け ることができるようになった。これらが今、 大きな社会的変革を起こしつつある。当初は 品質的にうるさくないものなど、たとえば白 黒のマニュアル印刷物などに変革が起こった。 
が今では高級カラー印刷物にまでデスクトッ プパブリッシング (DT P ) が浸透しつつある。

インターネットやオンラインデータベース で情報を受信するには、すくなくともパソ コンを持たなければならない。しかしコンピ ユータや通信のインフラストラクチャが整備 され、デジタル情報が統合的に扱えるように なれば、急激に制作・流通コストを押し下げ、 デジタルメディアによる情報変革が起こると 予測できる。これらのことを証明するかのよ うに 1998 年には日本のインターネット人 ロはすでに1０００万人を超えたとの報告が ある。

\section{2. メディアのマルチ化}

文字、図形、写真、に加えて音声や映像まで がデジタル化され統合化されると印刷、パッ ケージ、通信、放送など、伝達メディアの選 択の幅は広がる。またメディアの組み合わせ によるメディアミックスの考え方も広まるで あろう.ラジオが出現した時には寄席の危機 が叫ばれ、テレビが出現した時、映画や新聞 の危機が叫ばれた。しかしながらメディアは 確実に棲み分けられ進化してきている。CD - ROM やDVD(デジタルビデオディスク) が 出現し、インターネットや CS(コミュニケー ションサテライト)デジタル衛星放送が出現 してきた。さらには携帯電話の4000万台 という驚異的で爆発的な普及や自動車で実現 しているカーナビゲーションの浸透など移動 体通信 (モバイルコンピューティング)のイン フラストラクチャーも整いつつある。これら 多くの新しいメディアは、各々の特徴を生か す形で存在して行くであろう。メディアの最 適化こそ人々の望むことである。

メディアがマルチ化し始めると、書籍のよ うに連続した情報の列ではなく、いわゆる八 イパーメディアとなるように各種のリンク情
報を埋め込みながら情報を自由な観点から検 索したりするための工夫が必要とされ始めた のも新しい動きである。構造化された文章に 関する考察も必要となってきた。すでに当学 会でも取り上げているS GML化／XML化 の技術動向もいち早く取り入れる必要があっ た。印刷技術で培った表現技術をべースに、 より深く情報技術と係わって行くことが重要 となってきている。

\section{3.グローバル化、パーソナル化、オ ンデマンド化}

メーカの製品は地球規模で生産され消費さ れる。世界市場を相手にしなければならない しその方がメリットが大きい。したがってグ ローバルな情報を発信する必要があり、また グローバルな情報を受信することによってメ リットが享受できる。例えば当社でも日米欧 を結ぶデジタル網を構築し国際協業で納期短 縮を図ろうと計画している。また各人毎にセ グメントされた情報こそ大事であり、仕事の 範囲や趣味の領域、興味の梁さ、最大の関心 事など各人毎に異なる属性にあわせて受け取 りたい情報は異なる。これらパーソナル化さ れたセグメント毎に情報を伝達できれば喜ば れる。しかも好きな時に好きな形でオンデマ ンド化されれば好ましいし、瞬時に入手でき れば、なお好ましい。これらを可能にするの がデジタル化であり、データベース化であり、 ネットワーク化である。日本でも良いものを 安く仕入れるための資材調達に地球規模でイ ンターネットを使い始める企業も増加してい る。情報をコミュニケートするとは、まさに このことである。企業や消費者は限りなく新 しい要求をするし、経済的にも技術的にも可 能なことも増えてきた。

\section{4. コンテンツの制作と流通}


すべての情報はデジタル化可能である。次 のステップとしてはいかにデジタル化するか ではなく、何をデジタル化するかに変化して きた。何を本当に有効な情報として活用する か、あるいは出来るかになってくるであろう。 情報の中味・デジタルコンテンツこそが重要で あることも次第に認識されるようになってき た。すなわちコンテンツをいかにデータベー ス化し、検索し易いようにするかである。コ ンテンツの制作プロセスも変化し、また情報 を配布するにも最終的な配布の形体が紙でな いことも多い。したがってコンテンツをいか に集積し管理していくか、ネットワーク環境 下でどのようにデータベース化し管理してい くかである。データベースがしっかり管理さ れていればCD-ROM やインターネットでの 配信は容易であると考えて良いであるう。こ のような対応をしておけば、前節で述べたよ うにグローバル化、パーソナル化、オンデマ ンド化の要求に十分に応えられるであろう。

\section{5. 情報流通}

日本との比較でアメリカ経済の好況を反映 するかのように - $\mathrm{Xmas}$ の話題が報じられた のは、昨年暮れのクリスマス商戦の話題であ った。eはいわずもがなエレクトロニックの ことであり、e-Xmas はインターネットでク リスマスプレゼントを買う人が圧倒的に増加 したことを報じたのであった。

エルゼビアサイエンスの活動は当学会での 講演会などでもすでに発表されているが、知 的生産活動を支える学術論文に絞った情報流 通に関しては、一歩先んじていることは良く 知られている。学術論文誌の発行はもちろん のこと、インターネットで論文を全文検索で きるなどのサービスもすでに開始しているな どその先進性は他の比ではない。仕組み作り には長年にわたる試行錯誤がありまた料金を
徵収することなどに工夫を見せている。当社 でも、コンテンツパラダイスというサービス では、少額決済に便利なプリペードカード方 式のビットキャッシュカードを利用したコン テンツ販売を出版社に提案し、一定の評価を 得ている。また、東芝、電通と共同でネット 検索会社「フレッシュアイ」を設立するなど している。しかしさらに飛躍的に伸びてゆく ためには、いくつかの壁を乗り越えて行かな くてはならない。インターネットそのものが 無料だと感じている消費者に、「有効な情報 は、有料の対価を支払うことが当たり前であ る」と認識して貪うことなどである。

さまざまなエレクトロニックコマースの試 みが行われているにもかかわらず、日本での ネット通販が発展して行かないのは何故だろ うか? 米国ではアマゾンコム (http:// www.amazon.com/) が書籍の販売やCDの販 売などで着実にその利用者を伸ばし、自動車 の中古車販売 (http://www.autobytel.com/) の実績もかなりの金額にまで増加している。 知的生産活動においては、情報流通と決済流 通がうまくかみ合うことが前提であることを 述べたが、経済活動においては、情報流通と 決済流通のみならず物の流通がともなう必要 がある。当社でもトッパンセキュアモールを 立ち上げて情報流通と決済流通をできるよう に試みた。また昨年の暮れにヤマト運輸がネ ツト通販事業を支援するとの新聞発表をした が、これによってまた一歩前に進んだ感じが する。各メーカのホームページが一覧できる ことや、宅配時に物品との交換による代金決 済もできるなど、より安心できる通販スタイ ルが誕生しそうである。グーテンベルグが 印刷技術を発明して以来500年を経て、あ らたなメディア革命が誕生する。情流と金流 と物流の 3 拍子がそろえば経済活動そのもの の革命にまで発展して行くであろう。 


\section{6. 情報と知識}

さまざまな情報がデジタル化され統合化さ れることによって大きな変革が生まれてくる ことを述べた。一方知識に関してはどうであ ろうか?知識というのは記憶されいつでも取 り出し自由な形式で保存された知恵や複雑に 構造化された情報の集合体である。当社にお いても 10 年以上も前、知識工学や人工知能 という考えに基づき設計作業の専門家が持っ ている知識データベースとそれらを引き出す ための推論エンジンを用いて紙箱のCADシ ステムを開発し実運用を開始した。現在でも ダウンサイジングを経て基盤技術として定着 している。その際に知識というのはデータ蓄 積だけではどうにもならないことが解った。 すなわち単なるデータの集合だけではいくら 多くのデータを集めたとしても知識にはなら ない。整理された知識というのは相互の関連 性の固まりである。情報を知識にまで昇華さ せることが今後の大きな課題であろう。

\section{7. まとめ}

紙面上に文字や図形や写真などのデータを レイアウトして印刷物に仕上げていくプロセ スはD T Pで代表されるようにかなりデジタ ル化されてきたといえる。デジタル化率でい えば $80 \%$ 程度であろうか?しかしデジタル 化が顧客満足度にストレートに繋がるとは言 い難い。デジタルメディアにおいてはデータ ベースとネットワークが中核の技術になるで あろうし、さらにメディアは融合化してメデ ィアミックスやインターメディア、クロスメ ディアなどといったことがポイントになろう。 またネットワークが進展したときには従来の マスメディアとパーソナルメディアの棲み分 けや融合が進む。パーソナルコンピュータは 統合化されたデジタルメディアとなっていく
であろう。デジタル化が新たなドライビング ホースとなって行く事だけは間違いない。次 にこれらデジタル化される莫大な情報を知識 データにして行くための手法、技術に挑戦す べき時がくるのではないのだろうか?卵刷業 としても顧客満足度をあげながら紙媒体を活 性化し情報コミュニケーション産業として生 き延びていく事であると考えている。

現在の構造不況を乗り越えてゆくためには、 従来にない新しい考えや仕組みによって大幅 なコストダウンを計れる企業が生き残る。早 くこの問題解決に向かう事が重要だと思うの は筆者だけでは無いと思う。

\section{参考文献}

[1] インターネット白書“98. インプレス発 行. 1998 年.

[2] 日本印刷学会誌. 創立 70 周年記念、

Vol.35, No5, pp.235-236(1998).

[3] 印刷図書館ニュース.No.120(1998).

[4] 情報知識学会誌 SGML/XML 研修フォー ラム特別号. VOl.8, No.2, pp.25-26(1998).

[5] 変わり行く印刷産業の明日を考える.(株) 東レ経営研究所. 1998 年.

(1999 年 2 月 7 日受付) (1999 年 2 月 17 日採録)

\section{著者紹介}

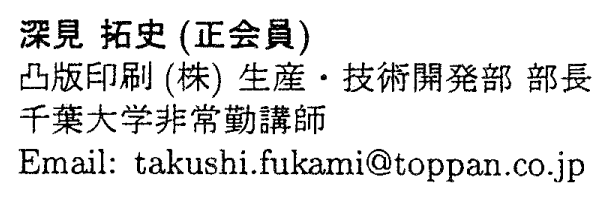




\section{Abstracts}

A Transdisciplinary Approach to Informatics - Common term, different usageKotaro Nawa

\author{
J.J.S.I.K., Vol.8, No.3, pp.2-6(1999)
}

'Reproduction' is one of essential terms in copyright law. But, the usage of the term in legal discipline differs from that engineering discipline concerned with information processing. This different usage for the common term throws interpretation of copyright law into confusion and disorder under digital environment.

\section{Multimedia and Information \& Knowl- edge in the Printing Industries Takushi Fukami \\ J.J.S.I.K., Vol.8, No.3, pp.7-10(1999).}

In this paper I described the current status and subjects in the printing industries. Specially the digital prepress process that mean the process of the preparing of the film for printing on the paper are glowing up with very high speed since several years ago. If all contents of the information will be digitized, then the information will be reused or remade for CD-ROM and on Internet. I described the development and the future of the multimedia. Recently the movement of the information distribution will be extremely changed. At last this article discussed how to change the communication industries from the printing industries

Fundamental Informatics and Its Applications to Hyper Brain Computers with Learning and Thinking Functions based on Conceptual Memory Structure

Yuzuru Fujiwara

J.J.S.I.K., Vol.8, No.3, pp.34-42(1999)

Since global information infrastructures are being developed, diversified and sophisticated requirements are given to a wide variety of multi lingual information. Hence, semantic understanding is inevitable for advanced functions e.g. analogical reasoning, induction, abduction for problem solving and decision support.

Semantic understanding is feasible by using self-organized semantic relationships among concepts by constructing conceptual structures carrying various and rich semantic relationships i.e. the learning function. Then thinking functions become feasible and hyper brain computers can be implemented.

These advanced functions are based on analyses information properties and information structures corresponding to semantic relationships among many kinds of concept which are represented by terms and other representation media. Methodology of these analyses , discovered principles and resultant theories are the main components of fundamental theory of information.

Effects of a New Teaching Method for University Students by Use of E-mails Schu Hirata

J.J.S.I.K., Vol.8, No.3, pp.43-50(1999)

A new teaching method to use E-mails practiced at Rissho university proved to be very effective for Japanese students who are commonly hesitant to speak out openly about their thinking and question at a class. They were requested to make responses weekly by E-mails to texts also delivered by E-mails. Through the experiments, the author analyzed a mechanism of learning not by casting knowledge as lecture but more effectively by giving students pieces of information which may be formulated in mind as knowledge by themselves. 